\title{
THE ISSUE IN ASSESSING LISTENING: WHAT LISTENING ASPECT MAY BE PROBLEMATIC ASSESSED TROUGH THE UTILIZATION OF TECHNOLOGY
}

\author{
Jaftiyatur Rohaniyah, Nasrullah \\ Universitas Islam Madura, STIBA Darul Ulum Banyuanyar \\ Javetien8@gmail.com, anastaciou88@gmail.com
}

\begin{abstract}
Assessing listening is the process of assessing the spoken text through the auditory insight. It requires the ability to recognize the spoken input with the auditory capacity and the knowledge of spoken language. The task and the activities are served in six listening types (reactive, intensive, selective, responsive, extensive and interactive listening) and the indicative answer is encoded by particular listening type focus on. While technology as vehicle to assess the learners' listening skill, that by using the technology much more spoken input are established by native-speaker and teachers' own record is used any. This study uses document analysis from the available previous studies to analyzing, evaluating and answering the problem which is encountered by student's listening and either or not technology used in assessing listening can help them to improve their listening ability. An overview of some researches provide that student get challenge to comprehend the native spoken input delivery such as, an accent, the length of speech, long spoken passage and linguistic feature. The authentic dialogue provides less density and length of the information than the dialogue created in the textbook, that the information incorporated in the machine/technology less improve the students' listening comprehension. It lacks to assess in the selective listening type that the task focus on taking the important information from the spoken text.
\end{abstract}

Keywords: listening assessment, challenge, technology

\section{INTRODUCTION}

In the language classroom four language skills should be assessed to rendering a progress for further learning and teaching. Teacher undertakes the most important role in assessing those skills and guarantee the quality of learning through classroom practice or activities which best supported students learning. In way of practices and activities assessed will engage student to monitor on and evaluate themselves in learning. The practice in the classroom is called as formative assessment that seeking for the extent and evidence of students' achievement which elicited and used by teacher to establish the next step of instruction. Teacher and student do kind of practice to know students learning, to identify the strength and weaknesses, to give some sources of information which are used by the teacher as the instructional planning and can be used by students to deepen their understanding to improve their achievement in teaching learning process. Therefore, assessment is considered as an umbrella used by the teacher in everyday classroom assessment practice and large-scale testing which is designed and administrated to the student (Lying\&Janna:2017). Teacher takes the assessment of students' performance whenever students answer to the question, offer an idea or comment, and do written work in ongoing process of assessment (Brown:2004). The merit of assessment employs in classroom make teacher never stop to assess the student incidentally or intended.

Listening is the most complicated skill to be assessed to the students than another language skill. It involves an oral input where the students must listen to and transfer the information on their mind through their auditory insight. In listening the information is given in spoken text so that students need hardest effort to recognize the information or the passage from what they hear unlike written text where student can read the whole passages in written form obviously. The presentation of spoken text 
become more problematic proved by test takers than the written input that relatively simple (Elvis:2014). A listening task and the item separated, the spoken text is giving orally by the speaker while the items provided in written. For instance, the items are the sort of questions given and the answer is taken from the spoken text that students should listen to spoken text and then select the appropriate answer in each of the items. The enticement for teachers is trying to copy the tasks and item types especially for requirement progress from institution (Glen\&Fred:2007). If copying the task and items from reading is easier through the available written than in listening which texts are much more available in audio record where teacher can only copy the task and item from the transcript of the audio without it teacher can't copy both of them except they make the audio record of the material by themselves. So that why teacher considered that listening is one of the most difficult task in teaching that he or she ever faced and so complex to improve students' competence (Natasha:2014). Does the students who may difficult to do the task while listening and respond to the teachers' question from the spoken input that they had heard without an authentic text.

Various tools can be used to assess student listening comprehension and competence. One of the tool employ in listening is the technology such as Audio and video record, and computer are an equipment of the technology which presented the spoken text. The technology used in assessing listening to academic students at majority, where the students has special listening class. Such as the audio present the spoken text base on related topic in listening syllabus for example the topic listening about the dialogue in traffic jump so that lecture assesses the student listening comprehension through what the speaker in dialogue are talking about. To comprehend the dialogue students not only listening but also recognizing to the speaker pronunciation because of all of the speakers are native and having different pronunciation style either British or American that they may or may not understand. It is challenge for students to deepen a pronunciation knowledge. And sometimes student listening comprehension is deficient because of the dialogue comprise of any hesitations and fillers used by speakers make conversation lack of direct and clear. These technologies equipment also used for assessing students listening comprehension in primary and secondary school but any because of their learning spend on reading, writing and speaking unlike the academic students. By using technology can help the teacher in saving their energy to not make their own record for spoken input where it is complicated way to do. But another side, assessing language use technology become controversial that the test design and the test items are limited marked by machine (Charles \& Lyle:2006). And the problem of the native speaker input which already set in technology that may not be manipulated, such the speakers utilize much of hesitation, the fast speed of the speech and pronunciation. However, the question formulated in this paper is" what the problems are encountered by student listening comprehension and do the use of technology help the students to access their comprehension during listening?

\section{REVIEW OF LITERATURE}

Assessing listening evoke a consideration through the complex skill of the spoken input for the auditory process to be assessed. Listening assessment requires an understanding in both of the construct and the ability which measured and the test task formats are identified in assessing the ability (Priyanvada:2018). In Listening process students or participant listen to the spoken inputs which are highlighted by the speaker. To attain a success of the listening input process, teacher must teach and deepen the knowledge of the spoken language to the students. According to Buck (2001:4) states that spoken language has three important characteristic of the speech which construct the listening comprehension they are: speech which is encoded by form of sounds, taking real time without chance of review and linguistic difference between spoken and writing). Firstly, the sound input is considered an acoustic input which represent the phonemes and not all phonemes encoded in the message clearly or unambiguously because of the sound is modified by speaker as considerably. In other sides sound 
input is considered in phonological modification that sounds are modified by the speaker base on phonological rules in normal speed speech either some sounds are modified with the sound next to them or another sounds are combined in the complex way and dropped in simple way. Secondly, the speech whirled in the recording technology is take place in the real time that speaker had set or determined the speed, the stress and the intonation on their speech. Listener can't ask the speaker to go back on their speech or even set the speech again unlike a speech or conversation without being record that listener can ask the speaker to repeat what they say in anytime. Thirdly, linguistic different between speech and writing that spoken language use shorter unit idea such as simpler syntax whereas writing tend to be complex syntax that make the information is more conveyed. Spoken establishes such as filler, hesitation, repetition and pause while writing does not. However, the listener input is tightened to these characteristic of speech during listening process.

Majority of listening skill is assessed by using a technology such as audio and video record, mobile phone and voicemail, online communication tool and so on. Technology has employed by researchers or practitioners who try to find out the way it is incorporated in education with the language learning as their field (Sylvie\&Linda:2011). In this book explains that the widely technology used is computer-assisted language (CALL) to promote learning and assess the learners' language. not only listening assessed by using computer but also another language skill such as reading, grammar and etc. Listening much more used a record that the file of the record or cassette is copied to the computer and later set it in the classroom. The texts task for assessment used in record are in form of dialogue or monologue (Dina\&Karin:2015), or the text in form of spontaneous and planed. It serves indicative answer of type of listening used in the task activity. there are six type of the listening (reactive, intensive, selective, responsive, extensive and interactive listening). for any types of the listening student need to comprehend for the indicative answer while teacher had selected the task activity with the particular listening types. In reactive listening the answer focus on the sound which is heard, intensive listening focus on the language form, responsive listening shows for an understanding, extensive listening focus on longer text with the connecting the idea, selective listening taking the important information such as location, time, and the last is interactive listening which assess by combining listening with speaking. Therefore, the selected text task in dialogue and monologues must be assessed in certain type of listening through the activity establishment.

Process of listening is considered in top-down and bottom-up and both are implied differently (Thomas\&Farrel:2013). In top-down process require listeners to rely on the meaning of spoken text using the information gotten from sound and word, listeners do the process in predicting, guising and interpreting the information they get. While bottom-up processing requires learners to recognize the lexical, linguistic feature such as pronunciation that more focus on language form. In real case toward assessing listening, teachers prefer to use the top-down process rather than bottom-down process. for instance, listening assessment is considerable with Listening process and listening type where the listening text, spoken input and the task criteria given. So that learning need to be carefully planned in how the learning activity and the task are designed and compiled by the teacher in order check the learners' understanding(Cheryl:2005). On the other sides, an unplanned learning can be one challenge for the students to understand the learning or even do the task because of the learning may implied boarder than what ever learn and teach and it seem ambiguous goal of learning. And the challenges emerge by speech rate, pronunciation and less of vocabulary and companied challenge by, speaker, message, listener and physical setting(Renukadevi:2014) in (Yagang,1994; Flowerdew and Miller,1996). The challenges for many students in university finds hard to cope the lectures' speed from the technical vocabularies are used (Andrew, Lucas, Gwendoline and John:2018). So, teacher must be aware to provide the appropriate listening assessment in encountering such the challenges.

\section{METHOD}

This study is qualitative descriptive method. It describes the phenomenon of the student's listening comprehension toward the spoken input given in assessing their listening comprehension. Some of the problems on the students listening comprehension which is emerged become the main case which will be discussed in this study. To investigate the exiting phenomena, researcher collect the 
data from the available previous research and then analysis the data which are found. In analyzing the data, it is used the document analysis technique to analysis, evaluate and answer to the problem which is encountered by the student in listening process and wither or not the utilization of the technology in assessing listening can help the students' listening progress or decrease that progress.

\section{FINDINGS AND DISCUSSION}

Listening is considered as the complex process to be assessed toward following and comprehending spoken input establishment. A widely spoken inputs are served by native speakers which has variant spoken language criteria. For those who are non-native may be difficult to expand their understanding of the spoken language being assessed, it may because their knowledge of spoken language is limited or they get problem with their auditory capacity. Despite of this, some studies highlight any of the issue in assessing listening and one of the issue is that, speaker input of spoken languages such as the speed of the speech, the accent, pronunciation and insufficient of vocabulary are affected EFL Saudi learners in lack of listening comprehension (Arafat:2013). The speed of speech become an issue in listening assessment because of the speakers' speed are too fast that make the learners not quite understanding of something being heard, it is being understood if the speech tends to be slower(Buck:2001). The accent and the unfamiliar of the vocabulary also become a problem in students' listening comprehension (Mustafa, Behcet, Naci \& Cagri:2014). It is quite deficient for the student in understanding different accent in spoken language where they are used to listen to the teachers' accents in daily classroom, so that teacher should familiarize between American and British accent to the student. through unfamiliar vocabularies can be a problem for the students, sometimes one word has the same meaning if it is used less common usage will make the students confused. However, any aspects of the speakers' spoken input evoke the problem of listeners listening comprehension for those become the major problem in listening assessment.

Another issue in assessing listening using combination between synthetic speech condition and human speech toward a game (Bowers, Husain \& Katelin:2014). It shows that game using synthetic speech does improve the listening ability while game used record of human improve the best performance. It can be concluded that the natural speech from the human encourage the students' listening comprehension as the speakers are non-native in how the student recognize easily to pronunciations which not so far different while natives' pronunciations are salient. According to Thomas and Farrel (2013:35) claim that many teachers are prefer to create their own recording in order to suit between their teaching objective and their students' need. As usual found that teacher's utilization of the speech is not quite fast and long passage unlike found in the recording of native speaker. the problem also shows that the use of oral passage is easier to comprehend by the students than the authentic passage, even it is authenticity, the authentic dialogue had found differ from the dialogue created from the textbook in the form of the length and density of the information (Sarah:2015).Sometime which is found in the listening class is one or two information from the recording passage do not provided in the authentic passage which become a failure of assessing listening information to the listener.

A limited time which spend in listening activity is little to improve the students' listening, and the inappropriate strategies and listening become problem too (Rara:2018). Teacher need to explore the variant of the listening type to the student in order they know the skill in what they have to do during the process and what the spoken knowledge assessed is listening type focus on. That is why an inappropriate strategy may not encourage the students listening comprehension progress and the inappropriate material does not support. The criteria in selecting the materials are based on the syllabus and the listening criteria need to suit with the level of the students and the extent of difficult level of listening, such the criteria of style of delivery, the speed length, level of difficulty, practicality and effectiveness (Qodir, Luqman \& Zain: 2016). The appropriate materials are become relevant to the students need and English ability especially and ability for listening skill. The use of the appropriate learning material and activities that teacher imply can be improved listening comprehension among 
VOL. 03 NO. 02, DECEMBER 2021

students(Seyedeh:2016). however, as what mention about some problems quite challenge for the teacher to assess student listening comprehension. It need an expand consideration such as the selection of the speaker's spoken input delivery on a record, the appropriate learning activities and material, the task design, an effort and appropriate teachers' own record, level of the student need and difficulty, and so on.

\section{CONCLUSION}

Assessing listening highlight an expand consideration through the spoken input transmitted to the students. Any of the spoken input served by native speaker become problematic in expanding the students' listening comprehension. A strategy in teaching, learning material and learning activity should evoke in relevant way for assessing listening. Teachers should strive to overcome those consideration, even it is quite challenge for them. Unfortunately, the use of technology which encode the available of the native spoken input establishment may not be changed. It because the recording speech had already set and any problems of the natives' spoken language emerge such as speed of speech, accent, linguistic feature and unfamiliar vocabulary. To handle this teacher can make their own record with the certain consideration.

In sum, the selection of the natives' spoken language delivery becomes a major problem encountered by students. the learning material and the teachers' own record should be suit with the students need and learning objective for better listening comprehension attainment. Perhaps, teacher need to create their own record in assessing listening for easier to help and increase the student's listening comprehension. It because nature of the teachers' record seems not quite complicated for the students unlike the record for native speaker which widely exposure the speech to fast, a salient accent and so far, on the other sides the authentic dialogue Less provided the length and density of information than the created dialogue in the textbook

\section{REFERENCES}


Andrew. J, Lucas. k, Gwendoline. G and John. P. (2018). Academic Listening Survival Strategies. ISBN. 978-988-78771-0-3.

Arafat, H. (2013). An investigation of Listening comprehension problems encountered by Saudi students in the EFL listening. international journal of academic research in progressive education and development.

Bowers, C, Husain, H \& Katelin, P. (2014). Assessing and improving listening skills: a test of two theories.

Brown, H.D. (2004). Language assessment: Principle and classroom practice. UK: Longman. Burk, Gary. (2001). Assessing Listening. Cambridge: Cambridge university press.

Cheryl, Jones. (2005). Assessment for learning. London: The learning and skills development agency.

Dina, T \& Karin, K. (2015). Handbook of Assessment for Language Teachers. Erasmus. ISBN 978-9925-7399-0-5.

Elvis. W. (2014). Assessing listening. Journal of the companion to language assessment.

Glen, F \& Fred, D. (2007). Language Testing and Assessment. USA: Library of congress cataloging

Lying. C \& Janna. F. (2017). Assessment in the Language Classroom. London: Palgrave \& Macmillan.

Mustafa, A, Behcet, C, Naci,Y \& Cagri, T.(2014). Listening comprehension difficulties encountered by students in second language learning class: Journal of educational and instructional studies.

Natasha, Walker. (2014). Listening: The Most Difficult Skill to Teach. Encuentro 23, ISSN 1989-0796.

Priyanvada. A. (2018). Technique for Assessing Listening. The TESOL encyclopedia of English language teaching.

QodiR, A, Luqman, B \& Zain. M. (2016). Developing Material of listening comprehension for the English department students. Journal on English as Foreign Language.

Rara, Saraswaty. (2018). Learners' difficulties \& strategies in listening comprehension. English Community Journal

Renukadevi, D. (2014). The role of listening in language acquisition: the challenges and strategies in teaching listening. international journal of education and information studies.

Sarah, Wayland. (2015). What makes listening difficult? Factor affecting second language listening comprehension. University of Maryland center for advanced study of language.

Seyedeh, M. (2016). The important of Listening Comprehension in Language learning. international journal of research in education.

Sylvie, T \& Linda, B. (2011). Second Language Teaching and Learning with Technology view of Emergent research. Dublin and Ireland: British Library Cataloging.

Thomas, S \& Farrell, C. (2013). Teaching Listening: English Language Teacher Development series. USA: TESOL International Association. 